International Journal of Linguistics, Literature and Culture
Available online at https://sloap.org/journals/index.php/ijllc/
Vol. 4, No. 6, November 2018, pages: $63 \sim 71$
ISSN: 2455-8028
https://sloap.org/journals/index.php/ijllc/article/view/408

\title{
Multiculturalism towards Religious Life in Tewang Tampang Village: Moral Education Implementation Based Local Wisdom
}

Article history:

Received: 18 July 2018

Accepted: 30 September 2018

Published: 27 November 2018

\section{Keywords:}

huma betang;

local wisdom;

multiculturalism;

philosophy values;

togetherness;

\begin{abstract}
This article at examining the implementation of the multiculturalism principle in religious life at Tempang Tewang village. This principle was successfully implemented by the villagers. Inter-ethnic conflict due to the differences in understanding and articulating religious teachings in everyday life. In Indonesia, in recent decades, it is a reality that cannot be denied. The different conditions actually occurred in religious life. This article was presented based on qualitative analysis. The data were obtained through observation and interviews. The observation was conducted in a nonparticipatory and women's manner was in a deep interview. The results showed that the multiculturalism maintenance in religious life was due to huma betang philosophy values included equality and togetherness (hapahari), mutual cooperation (handep), ethical life (belom bahadat), and consensus (hafakat basarah). The conclusion was local wisdom (huma betang) implemented by the villagers. It was one manifestation of the multiculturalism principle.
\end{abstract}

2455-8028 ${ }^{\circledR}$ Copyright 2018. The Author. This is an open-access article under the CC BY-SA license (https://creativecommons.org/licenses/by-sa/4.0/) All rights reserved.

\section{Author correspondence:}

Rahmawati,

Institut Agama Hindu Negeri Tampung Penyang (IAHN-TP), Palangka Raya, Indonesia

Ph. +62 813-8834-6368

Email address: ninyomanrahmawati0202@gmail.com

\section{Introduction}

Religious multiculturalism in the midst of Indonesian people life is a necessity. This is due to government policy through the Determination of President of the Republic of Indonesia No. 1/PNPS in 1965 concerning Abuse Prevention and/or Religion Blasphemy. Its explanation stated that official religions recognized in Indonesia included

\footnotetext{
${ }^{a}$ Institut Agama Hindu Negeri Tampung Penyang (IAHN-TP), Palangka Raya, Indonesia

${ }^{\mathrm{b}}$ Universitas Udayana (UNUD), Denpasar, Indonesia

${ }^{\mathrm{c}}$ Universitas Hindu Indonesia (UNHI), Denpasar, Indonesia
} 
Muslim, Christianity, Catholicism, Hinduism, Buddhism, and KhonghuCu (Confucius). This policy, in reality, encourages the multiculturalism occurrence of life not only occur in the midst of the society but also occurred in the families. One of them is religious multiculturalism in Dayak people life at Tewang Tampang Village, Katingan Regency, Central Kalimantan. The difference in religion did not trigger conflict, but rather they can live peacefully and harmoniously in carrying out their daily lives.

According to Kurdinal, one of mantir adat (custom leaders), there has never been a religious conflict in Tewang Tampang Village. He stated that people live in different religions had always been in harmony and helping each other (interviewed July $20^{\text {th }}$, 2017). This can be happened, due to the local wisdom values of the local community still used as a guide to morality in daily social interactions. In addition to the moral values taught by each religion. One of the values of local wisdom is still used as a guide to morality in conducting social interactions is the values contained in huma betang philosophy. Usop (2011), stated that huma betang is a value system or norm of community life based on kinship, togetherness, equality in civil society. It comes from the philosophy of Bhineka Tunggal Ika (Unity in Diversity) is a substructure of Pancasila (PBBKT: 2003).

The values and norms of social life consisted in the philosophy of huma betang as local wisdom value for the community are still guided and used as a basis for morality education in the family and the society. In addition to the religious moral values adopted by their respective communities. Therefore, it is very important to examine how the implementation form of the philosophy of huma betang (local wisdom) towards peace and harmony of religious life.

\section{Materials and Methods}

This article is presented based on qualitative analysis. The data were obtained through observation and interviews in Tempang Tewang Village. The observations were conducted in a non-participant manner and interviews were conducted in a deep interview. The informants were determined purposively and snowball. Data processing was done in three stages included data reduction, data presentation, and data verification/conclusion.

\section{Results and Discussions}

\section{Multiculturalism principles implementation in religious life}

Multiculturalism is a necessity occurred in the midst of the society in Indonesia. This is due to Indonesia itself is different from custom and culture, there are also six official religions recognized by the state included Muslim, Christianity, Catholicism, Hinduism, Buddhism, and KhonghuCu (Confucius). Thus, the difference in religion embraced in the midst of the society is a reality that must be accepted by everyone. In order to avoid the occurrence of the religious conflict in the midst of religious multiculturalism is embraced by the current society. The concept has been conceived. It is believed to unite all religious communities, i.e., religious multiculturalism. It recognizes that every true religion is the same to achieve goodness for humanity religious attitude that recognizes and respects the truth in the teachings of other religions. Blum (1991), stated that multiculturalism included an understanding, appreciation, and assessment of one's culture, as well as a respect and curiosity about other ethnic cultures.

The religious multiculturalism idea in Indonesia was not to work as expected. There are still many religious people who understand that religious multiculturalism is a form of understanding that equates every religious teaching (religious pragmatism). This triggered various differences in responding to the emergence of religious multiculturalism in the midst of society. Hick (1985), quoted by (Safii, 2012), three religious attitudes that exist in society was addressing religious multiculturalism, i.e., religious attitudes: exclusivism, inclusivism, and pluralism.

The attitude of religious exclusivism is a religious attitude that only looks at its religious truth in black and white. The truth is only possessed by the religion adopted. The other religion is heretical. Inclusivism is a religious attitude that is more flexible in looking at the truth of another person's religion. The inclusivism viewed the absolute truth is only possessed by the religion they profess, but they try to recognize the truth that is owned by other religions. However, the truth is due to the abundance of the absolute truths religion has. A multiculturalism viewed every religion as having truth and their own way to achieve the desired goal. Due to they must be understood from the standpoint of their truth.

The above religious attitudes description for the society in Tewang Tampang Village tend to have a pluralism diversity. Therefore, they are able to live peacefully and harmoniously with each other. It can be seen in the 
interactions in their daily life, unlike the festival day religion, e.g., Christmas celebrations held by Christians who are also attended by their brothers who adhere to Muslim and Hindu Kaharingan as shown in figure 1:

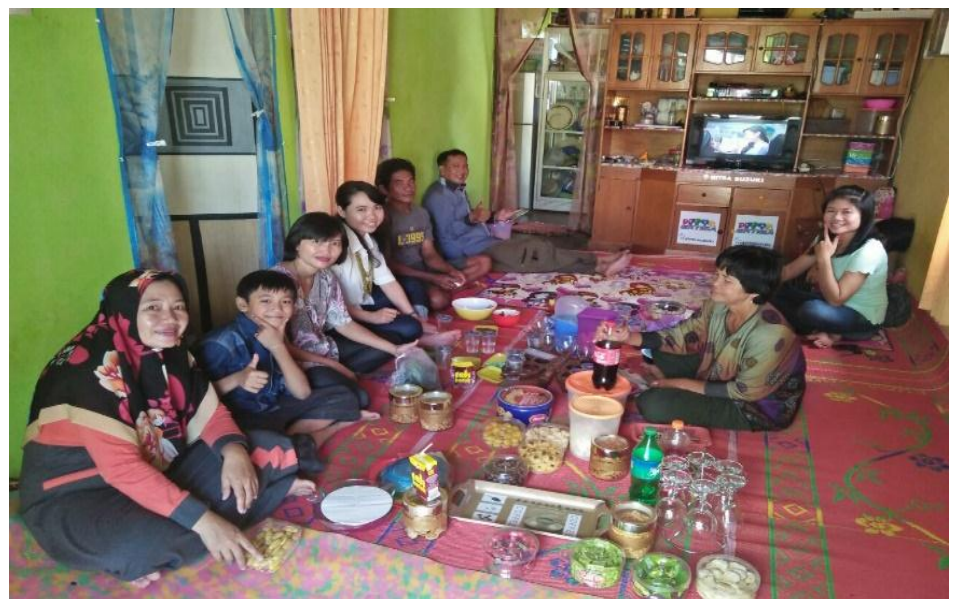

Figure 1. The togetherness during Christmas Day in Tewang Tampang Village

(Doc. Rahmawati, 2017)

Figure 1 above shows the togetherness of the family in Tewang Tampang Village during the Christmas Day. Even though they adhere to different religions, they are still present to respect their brothers/sisters when commemorating religious holidays. In addition to hospitality, they were also present to help prepare everything needed for the celebration. Likewise, if their other brothers are commemorating their religious interfaith holidays, they also come to help. Besides, being together during the celebration of the religious day, the togetherness of this model is also evident during the implementation of family rituals as figure 2 :

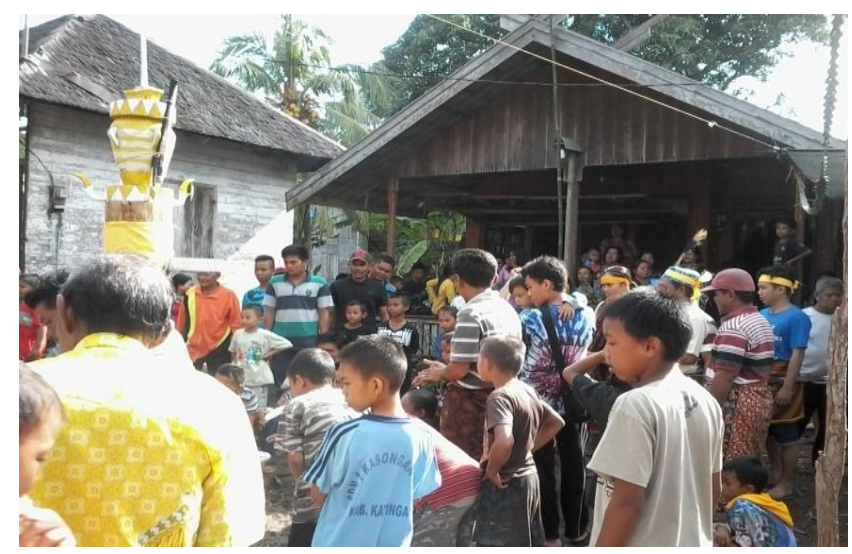

Figure 2. The togetherness in conducting family rituals

(Doc: Rahmawati, 2017)

The societies who are Hindu Kaharingan, Muslim, and Christianity together still conduct family rituals as an inheritance from their ancestors. In the implementation, this ritual is conducted through various deliberations. There is no misunderstanding in the implementation even though they are different in terms of religious ideology. According to Wardi, one of the Muslim who still carries out a family tradition stated that Muslims and Christians in the village mostly still believe in family traditions inherited from their ancestors, except the implementation is adjusted to their respective beliefs (interviewed July $18^{\text {th }}, 2017$ ).

Rahmawati, N. N., Kumbara, A., \& Suda, I. K. (2018). Multiculturalism towards religious life in tewang tampang village: moral education implementation based local wisdom. International Journal of Linguistics, 


\section{Philosophy implementation of huma betang as morality education base}

Globalization as an openness era in modern times, bringing positive influence is also inseparable from the negative influence on people's lives. The ease of accessing various social media content unlike the door for the entry of outside cultures sometimes not to fit the values and customs of the Indonesian people. One of them is the radicalism inclusion prone to trigger conflicts in the midst of the Indonesian people who live in a variety of religions, customs, and cultures. Therefore, it is necessary to have a fortress is able to filter the influence of the global culture. Thus, the joints of the national life based on eastern customs did not become disappear. One of them is morality education. Bertens (2002), stated that morality is a moral or overall principle and values being good and bad. In accordance with Keraf (1993), stated that morality acts as a regulator and guidance for humans in behaving. It can be categorized as a good human being and can avoid bad behaviour (Sukarma, 2016).

A morality education is based more on the religious teachings adopted by each individual. It teaches about how to behave good and right in the midst of life in the multicultural society. Every religion has its own teaching value in viewing what is good and not good for the people to do based on their respective ideologies. The differences in looking at what is good and not good, what may or may not often trigger conflict in the midst of the society. It is inseparable from the ambivalent nature of religion as stated Durkheim (2005), the religious pluralism has the potential to cause conflict. It can invite controversy even though religious ontologies originate from a single reality and esoterically all religions teach the same thing. The teachings taught by each religion revolve around the teachings on love, mercy, and dharma. However, in reality, religion is ambivalent, the love teachings of religion being a uniting factor as well as religion is also a dividing factor (Arifin, 2005).

The morality education should not only source from the teachings of religious morality but also be balanced with moral values have been possessed by Indonesian ancestors as part of the local genius. The local genius value is owned by each community in Indonesia. It is the noble values of life inherited by ancestors in the social life. It is as a basis for morality education is a tradition that has been carried out by the people in Tewang Tampang Village for generations. Based on data, almost $90 \%$ of people live in religious diversity e.g., Muslim, Hindu Kaharingan, and Christianity. According to Kurdinal so far there has never been a religious conflict in the village. This is due to there still keep it up to various values of life that have been taught by their ancestors. It is the philosophy of huma betang (interviewed July $20^{\text {th }}, 2017$ ).

Huma betang is a traditional building form for Dayak people in Kalimantan. This building has a variety of local wisdom values still guided and used as a foundation of morality in social interaction by local communities in maintaining peace and harmony in religious life. The philosophy of huma betang is the values of togetherness for Dayak tribe. They still meditate on, one of them is Tempang Tawang community who used to live in a longhouse with various differences. Usop (2001), a cultural observer who often studies and explores the culture of the Dayak Ngaju people, in his conclusions about huma betang stated that the culture of betang (longhouse culture) is a system of values or norms for the community life based on kinship, togetherness, equality in civil society, and as a subculture of Pancasila.

Riwut et al., (2006), stated that betang culture is a metaphor of togetherness in the daily lives for Dayak people who used to live in the betang house. It is unlike life tradition of indigenous people of Kalimantan in the past. It is not just a place to live together to shelter and gather, more broadly than huma betang is the center of social structure in their lives. Various rules to bind the behavior of each occupant are agreed upon it is then poured into customary law. Riwut et al., (2006), further stated that the prominent value in life in betang house is the communalism value among huma betang societies. Abubakar (2016), also stated that huma betang as a culture that historically and sociologically has the value of local wisdom can bind the unity sense and the unity among Dayak tribes generally. The value of local wisdom consisted of the philosophy of huma betang and used as a guide in morality education in Tewang Tampang Village included:

\section{a) Value of equality and togetherness (hapahari)}

The value of equality among human beings is explicitly expressed in the core culture and philosophy of huma betang like berdiri sama tinggi duduk sama rendah di mana kaki dipijak di situ langit dijunjung ("standing and sitting at the same height/low, where the feet stand where the sky is upheld.") This philosophy contains very high human values for mutual respect in carrying out social interactions between religions and cultural customs that exist. This attitude is currently very much needed to maintain and respect each other's differences in cultural and religious 
customs that are owned by each group and individuals in the midst of an increasingly widespread stream of globalization to avoid division as a nation's children.

The absence of the class differentiation in the lives of Tempang Tawang people shows the value of togetherness in the humanity degree in the social interaction. Normatively, this value actually strengthens the brotherhood bond among the different society of huma betang. It is reflected in the togetherness of the society of huma betang in developing, maintaining mutual harmony. Unlike to foster togetherness values are egalitarian, communal, solider, and help. This value of equality is reflected in the social life in Tewang Tampang Village who always treat their relatives who have converted. For them, the different religions are not a problem due to religion is only a way to guide them towards the same goal. However, behind their religion, they are bound regional ties that will not be separated until death. Thus, their lives even though they are different in religion but still keep each other and help each other in togetherness.

The local term is often used as a moto in expressing togetherness for the community in Tewang Tampang Village is "sama keme, sama mangat, sama susah". This moto consisted of the value of life attitude philosophy as huma betang occupants, i.e., both bear, even being joy and sadness. The value of this life philosophy is still very thick practiced by the community. However, due to they did not live in a betang house, this attitude was activated through sharing food with fellow relatives, and closest neighbors. Ernawati, one of the residents in Tewang Tampang Village, stated that the habit of sharing food for the community in her village is a hereditary habit, especially with fellow brothers and sisters. Thus, there is one life principle they hold firm, i.e., living in a temporary manner. There are brothers and neighbors who are starving (interviewed July $24^{\text {th }}, 2017$ ). Therefore, this value of equality and togetherness is still being emulated by the people in Tewang Tampang Village.

\section{b) Value of mutual help (handep)}

The philosophy value of huma betang is still visible in the social life in Tewang Tampang Village. It is a value of handep. According to Suwarno (2007), handep is an attitude of mutual helping, pandohop (help), saling mandohop (helping each other). Handep is for Tewang Tampang Village is very clearly seen in their social life, especially if there are death and marriage rituals. Regardless of the differences in religion, they hold currently. If there is death or marriage ritual together, they come together to help without coercion. The attitude of helping in the life of the Tempang Tawang community is still used as a principle in living the life of multiculturalism. For them living in this world cannot be separated from the existence of other people due to they must be able to always live side/neighbour even though they have different religions. A religion for them is only a tool to achieve the same life goal.

\section{c) Value of belom bahadat}

Belom bahadat is a behavior that upholds honesty, equality, togetherness, and tolerance. It is obedient to the law. Belom bahadat attitude social life in Tempang Tawang is highly upheld. According to villager, from the child, they have been invested in how to become law-abiding people and the rules. It applies in their environment so that they have social ethics. It is not only related to fellow humans but also in protecting the environment. For the people in Tewang Tampang Village, not adhering to customary law and various aspects in their beliefs, they will be fatal in their lives as well as the environment. In fact, according to Kurdinal, there are two sanctions will befall those who violate the norms and customary law in Tewang Tampang Village, namely social sanctions in the form of scorn as human dea bahadat (uncivilized) and customary sanctions in the form of jipen (fines) can be in the form of money or rituals to neutralize the adverse effects due to their violations done.

\section{d) Value of hapakat basara (deliberation of consensus)}

The value of hapakat basara (deliberation of consensus) in their social interaction is very evident in their efforts to solve various problems faced. Unlike in carrying out family rituals (family traditions). In general, although most people in the village have converted to Muslim and Christianity, in their daily lives they still practice various family traditions passed down through generations. Like the ritual of parasih pambak/parasih kubur (a ritual to honor the spirits who those have died). In its implementation, according to Yena, one of the residents who has converted to Muslim is always done through deliberations with their relatives who are Hindu Kaharingan and Christian. The aim will be no misunderstanding in the implementation due to differences in perspectives on materials and procedures will be used.

Rahmawati, N. N., Kumbara, A., \& Suda, I. K. (2018). Multiculturalism towards religious life in tewang tampang village: moral education implementation based local wisdom. International Journal of Linguistics, 
e) Communicative attitude as an implication of religious local wisdom in social diversity

The philosophy of huma betang as the value of local wisdom in Tewang Tampang Village emphasizes the values of equality and togetherness as a society. It is open in accepting the differences, nowadays, grows a communicative religious attitude among the community. The nature of the communicative religiosity according to Mulkhan (1995), is a religious nature that does not contradict humanitarian extremes in the form of historical culture with absolute divine values. It can be drawn in a communicative and dialogical relationship from such religious attitudes. The confrontation between welfare dynamics and religious normativity can be avoided. The communicative attitude of the people is very evident during the practice of family rituals, the celebration of the religious rituals, the occurrence of disasters and other community activities. An interfaith communicative attitude arises when each believer establishes contacts or interactions that can minimize misunderstandings. It efforts to reduce iterative behavior, prejudice, and misunderstanding between them. Menoh (2015), stated that in the public space there was a process of mutual learning among secular citizens and religious citizens, and among citizens of different religions. This condition is called Habermas (2008), post-secular society (postsakulare gesellschaft).

The religious teachings have a big influence in uniting the perceptions for the social life. Regarding all life expectancies as one of social life directions whose policing process is more systematic and ingrained. In policing the social behavior of religion enters the human conscience. Therefore, the main mind searching for the meaning of life is not perfect. If the religious teaching substance is not used as the most important reference epistemologically or axiologically. In the context of religious multiculturalism, the acceptance of the common vision, this means reconnecting to many, in this case, the exoteric reality of religions, to the origin of The One (God), who were given various names by followers of various religions in line with cultural developments and human social and spiritual awareness. Thus, the empirical impression of the existence of diverse religions does not just stop as a factual phenomenon. However, continuing to the real flow is the same binding of these religions, in symbolic language is referred to as religion itself (Jamaludin, 2003).

The communicative religious attitude towards Tewang Tampang Village community is reflected in their openness in accepting the differences. This can be seen from their willingness to communicate related to religious practice issues in the family, community, and the surrounding environment. The willingness in attending various religious activities carried out by families of different religions, and willingness to help other communities affected by disasters despite different religions. It is clear proof of the implementation of the multiculturalism principle among the people in Tempang Tawang very well. This can be seen from the agreement that they took in consensus. It did not deviate from the teachings of their religion. The way of consensus in bridging the differences that exist in the midst of a society in Habermas (2018), viewed is referred to as communicative action, namely symbolic interaction determined by consensus norms that binds both parties and guarantees their respective visions and hopes. The success of a communication is not determined by its actions but is determined by the achievement of mutual understanding (Hardiman, 2009b).

\section{Conclusion}

The implementation of the multiculturalism principle for the community in Tempang Tewang can be conducted very well. It can be seen from their togetherness in social interactions unlike religious practices in the family and society. This can be happened, due to the existence of local values and norms from the philosophy of huma betang is still guided as the norm in social interaction, both with others and the surrounding environment. There are four values and norms from the philosophy of huma betang are still being studied in the lives of people in Tewang Tampang Village, including equality and togetherness (hapahari), help each other (handep), honesty and lawabiding (belom bahadat), and deliberation for consensus (hapakat basara). The value and norm of the philosophy of huma betang in Tewang Tampang Village have implications for the religious attitude of the people who are increasingly open in accepting differences. It can be seen from their willingness to carry out various communications in solving religious problems, both within the family and in the midst of the community. Thus, it can be concluded briefly that the multiculturalism principle life in Tempang Tawang community is very well.

Conflict of interest statement and funding sources

The authors declared that they have no competing interest. The study was financed by personal funding. 
Statement of authorship

The authors have a responsibility for the conception and design of the study. The authors have approved the final article.

\section{Acknowledgments}

The author would like to thank all parties, especially to promotor, co-promotor, informants, and colleagues for their guidance, support, and motivation. Therefore, this article can be completed on time. It is hoped that this article can be useful for further research in the field of multiculturalism.

Rahmawati, N. N., Kumbara, A., \& Suda, I. K. (2018). Multiculturalism towards religious life in tewang tampang village: moral education implementation based local wisdom. International Journal of Linguistics, Literature and Culture, 4(6), 63-71. https://doi.org/10.21744/ijllc.v4n6.408 


\section{References}

Abubakar, H. M. Huma Betang Dan Aktualisasi Nilai Kearifan Lokal Dalam Budaya Dayak. Humanika, 1, 259-294.

Arifin, S. (2005). Ideologi dan praksis gerakan sosial kaum fundamentalis: Pengalaman Hizb al-Tahrir Indonesia. Penerbitan Universitas Muhammadiyah Malang.

Bertens, K. (2002). Filsafat Barat Kontemporer Inggris-Jerman. Jakarta: PT Gramedia Pustaka Utama.

Blum, L. (1991). Moral perception and particularity. Ethics, 101(4), 701-725. https://doi.org/10.1086/293340

Durkheim, E. (2005). Suicide: A study in sociology. Routledge.

Habermas, J. (2008). Notes on post-secular society. New perspectives quarterly, 25(4), 17-29. https://doi.org/10.1111/j.1540-5842.2008.01017.x

Habermas, J. (2018). The philosophical discourse of modernity: Twelve lectures. John Wiley \& Sons.

Hardiman, B.F. (2014). Komersialisasi Ruang Publik Menurut Hannah Arendk dan Jurgen Habermas: Dalam Ruang Publik Melacak Partisipasi Demokratis dari Polis sampai Cyberspace. Yogyakarta: Kanisius.

Hick, J. H. (1985). Problems of religious pluralism. Springer.

Jamaludin, A. N. (2015). Agama \& konflik sosial: studi kerukunan umat beragama, radikalisme, dan konflik antarumat beragama. Penerbit Pustaka Setia.

Keraf, G. (1993). Komposisi: sebuah pengantar kemahiran bahasa. Nusa Indah.

Menoh, G. A. (2015). Agama Dalam Ruang Publik: Hubungan Antara Agama dan Negara dalam Masyarakat Postsekuler Menurut Jurgen Habermas. Kanisius, Yogyakarta.

Mulkhan, A. M. (1995). Teologi kebudayaan dan demokrasi modernitas. Pustaka Pelajar.

Riwut, T. (2006). Pergulatan identitas Dayak dan Indonesia: belajar dari Tjilik Riwut. Galang Press.

Safii, S. (2017). Pluralisme agama sebagai rahmatan li al-'alamin. Jurnal Theologia, 23(2), 430-446. http://dx.doi.org/10.21580/teo.2012.23.2.1677

Sukarma, I. W. (2016). Tri Hita Karana theoretical basic of moral Hindu. International Journal of Linguistics, Literature and Culture, 2(3), 102-116.

Suwarno, S. (2017). Budaya huma betang masyarakat dayak kalimantan tengah dalam globalisasi: telaah konstruksi sosial. Lingua: Journal of Language, Literature and Teaching, 14(1), 89-102. http://dx.doi.org/10.30957/lingua.v14i1.237

Tim Penyusun. (2003). Adat Istiadat Dayak Ngaju. Palangaka Raya: LSM PBBKT

Usop, T. B. (2011). Kearifan Lokal Dalam Arsitektur Kalimantan Tengah Yang Berkesinambungan. Jurnal Perspektif Arsitektur, 6(1), 25-32. 


\section{Biography of Authors}

\begin{tabular}{|c|c|}
\hline & $\begin{array}{l}\text { Ni Nyoman Rahmawati, S.Ag., M.Sc., is a lecturer in Institut Agama Hindu Negeri } \\
\text { Tampung Penyang Palangkaraya. She graduated her bachelor degree in STHN-TP } \\
\text { Palangkaraya, department of Hindu education in 2008. She finished her magister } \\
\text { degree in Universitas Hindu Indonesia (UNHI), department of religion and culture in } \\
\text { 2010. She currently a doctoral student in the faculty of arts, Universitas Udayana. } \\
\text { Email: ninyomanrahmawati0202@gmail.com }\end{array}$ \\
\hline & $\begin{array}{l}\text { A. A Ngurah Anom Kumbara, is the faculty of Arts, Universitas Udayana since } 1983 \text {. } \\
\text { He graduated his bachelor degree in anthropology at Universitas Udayana in } 1982 . \text { He } \\
\text { finished his master degree at Universitas Indonesia in 1990. He completed his doctoral } \\
\text { degree at Universitas Gajah Mada in } 2008 \text {. He is a professor of anthropology } \\
\text { epistemology in } 2010 \text {. He was writing books entitle local elite contest representation of } \\
\text { power and identity relations (2012), anthropological discourse, rereading cultural texts } \\
\text { towards self-transformation in multiculturalism ( } 2013 \text {, Editor) and article entitle } \\
\text { application of democracy and multiculturalism in the parikrama village community in } \\
\text { Bali, in Jnana Budaya journal. social conflict, and resolution on multicultural } \\
\text { communities in Denpasar city, in jnana budaya. Chronic disease management by Balian } \\
\text { usada on ethnic Bali, and genealogy theories and methods in cultural studies, E- } \\
\text { Cultural journal, 2018. } \\
\text { Email: anom_kumbara@unud.ac.id }\end{array}$ \\
\hline & $\begin{array}{l}\text { Prof. Dr. I Ketut Suda, M.Si was born in Tegallalang, } 31 \text { December } 1962 \text {. He is a } \\
\text { professor in the education of sociology at Universitas Hindu Indonesia (UNHI). His } \\
\text { education background for S-1 (bachelor degree) finished in the education of the } \\
\text { pancasila and kewarganegaraan program, FKIP UNUD Singaraja. He completed S-2 } \\
\text { (master degree) in the master program of cultural studies at Universitas Udayana } \\
\text { Denpasar. He got the doctoral degree in cultural studies at Universitas Udayana } \\
\text { Denpasar. He teaches for the postgraduate program of UNHI Denpasar. The office is } \\
\text { located at Jalan Sanggalangit, Tembau, Penatih, East Denpasar. Phone/Fax: +62361 } \\
464800 /+62361464700 \text {, Ph. +6287862382983. He lives at Jalan Antasura Gg. Batusari } \\
\text { I No.1 Denpasar Utara, Bali, Post Code: } 80115 \text {, Ph. +62361 } 415938 \text {. } \\
\text { Email: suda.unhidps@yahoo.co.id }\end{array}$ \\
\hline
\end{tabular}

Rahmawati, N. N., Kumbara, A., \& Suda, I. K. (2018). Multiculturalism towards religious life in tewang tampang village: moral education implementation based local wisdom. International Journal of Linguistics, Literature and Culture, 4(6), 63-71. https://doi.org/10.21744/ijllc.v4n6.408 